\title{
Application of Risk Management and Patient Safety to Ensure Legal Pro- tection for Patients and Health Personal Services in General Hospital of Abepura City of Jayapura
}

\author{
Penerapan Manajemen Risiko Dan KeselamatanPasienUntuk Menjamin Perlindungan \\ Hukum Bagi Pasien Dan Tenaga Kesehatan Pada Pelayanan Rumah Sakit Umum Daerah \\ Abepura Kota Jayapura
}

Hendrik William Rumbewas, Yovita Indrayati, Hadi Sulistyanto

email: rumbewashendrik@gmail.com

Health Law Master Program, Soegijapranata Catholic University of Semarang

\begin{abstract}
The problem in this study is how to regulate and apply Risk Management and Patient Safety to ensure Legal Protection for Patient and Healthy Person at Abepura General Hospital, and what obstacles faced by Hospital in arranging and implementing Risk Management to ensure legal protection seen from involvement legal rules and technical aspects such as human resources, culture, politics, facilities and others. The purpose of the study is to obtain a description of the application, arrangement, and barriers pelksanaan Risk Management and Patient Safety to ensure the Legal Protection for Patients and Health Personnel at Abepura General Hospital, which is viewed from the side of involvement of the rule of law and the technical side such as human resources, culture, politics, facilities, and others.
\end{abstract}

This research is an analytical, descriptive legal research, with the approach of Sociological Juridical, this research examines the problem of applying risk management and patient safety in giving legal protection to patient and health worker. To answer the problem, secondary date, primary date, and tertiary date are needed. Secondary date in the form of primary date collected through field study and secondary date collected by library study

So the results of the study obtained on setting the hospital's internal rules in the form of hospital by low and operational standards used in hospitals has not functioned as a legal tool used to minimize the risk if there is a problem in RSUD Abepura, because the device rules still need penyempunaan material with takes a long time and adjusted to the ability and state of the hospital. Thus the form of risk must always be guarded by active regulatory oversight in providing periodic evaluations and monitoring. Implementation of risk management has not become a legal tool in use in supporting the Abepura Regional General Hospital service and has not become a key regulation in ensuring patient safety. Therefore, the local regulations are the basis of the guidelines in performing services to ensure patient safety and protect patients and health workers. So it has not yet illustrated the relationship between the implementation of risk management and patient safety due to the level of compliance with existing regulations and resulted in the form of misunderstanding between the patient, the patient's family, and the health worker. Obstacles to the implementation of risk management regarding the Normative side of the hospital has not understood the contents of regulations and policies on $\mathrm{Pa}$ tient Safety and not by the policy for patient safety cases in the hospital. From the technical side includes the function of coordination of service duties associated with several factors such as supporting facilities such as skilled health officers who supported facilities in the form of complementary facilities such as buildings and medical equipment which also become an 
obstacle in improving the quality of services in tunjang also with allocation funds that are not in accordance with the needs of the hospital, so that the escort to risk has not yet disputed the dispute between the patient and the health worker.

Keywords: Risk Management, Legal Protection, Patient

\section{PENDAHULUAN.}

Kesehatan Merupakan Elemen Terpenting Dalam Kehidupan. Upaya Peningkatan Kualitas Kesehatan Memberikan Makna Pada Kemampuan Hidup, Baik Secara Rohani Maupun Fisik. Wujud Hidup Sehat Merupakan Tujuan Dan Cita-Cita Nasional Bangsa Indonesia, Seperti Yang Tertuang Dalam Pasal 28 H Ayat (1) Undang-Undang Dasar Tahun 1945 Mengatur:

"Setiap Orang Berhak Hidup Sejahtera Lahir Dan Batin, Bertempat Tinggal, Dan Mendapatkan Lingkungan Hidup

Yang Baik Dan Sehat Serta Berhak Memperoleh Pelayanan Kesehatan".

Keadaan Hidup Sehat Selalu Menjadi Harapan Bagi Setiap Warga Negara. Oleh Sebab Itu, Untuk Memperoleh Hidup Sehat Dibutuhkan Berbagai Tindakan Yang Dapat Dilakukan Masyarakat Itu Sendiri Dengan Perilaku Hidup Sehat Yang Didukung Pelayanan Kesehatan Oleh Rumah Sakit. Rumah Sakit Merupakan Salah Satu Sarana Pelayanan Kesehatan Yang Telah Disediakan Oleh Pemerintah Atau Badan Usaha Swasta Guna Memenuhi Kebutuhan Pelayanan Kesehatan Masyarakat.

Upaya Pemerintah Dalam Menyediakan Sarana Pelayanan Kesehatan Tersebut Merupakan Bentuk Pemenuhan Hak Atas Kesehatan, Dan Pemerintah Mempunyai Tanggung Jawab Menjamin Dan Meningkatkan Kesejakteraan Masyarakat.Ditunjang Oleh Prinsip Pelayanan Kesehatan Yang Mempunyai Maknamelindungi. Pernyataan Melindungi Yang Merupakan Tangung Jawab Pemerintah Tersebut Diungkapkan Oleh Elizabeth Siregar Dan Arrie Budhiartie ${ }^{1}$ Bahwa:

“Dalam Melakukan Penyelenggaraan Pelayanan Kesehatan Merupakan Kewajiban Bagi Pemerintah Karena

Dalam Membangun Masyarakat Yang Sehat Dan Produktif Harus Dilandasi Pada Kesadaran Akan Segala Bentuk

Hak Dan Kewajibannya Sebagai Warga Negara Dan Anggota Masyarakat”.

Selain Memperhatikan Kesejakteraan Masyarakat Secara Umum, Pemerintah Juga Berupaya Menjamin Nilai Perlindungan Terhadap Apa Yang Diterima Dalam Pelayanan Kesehatan. Upaya Tersebut Berupa Jaminan Perlindungan Hukum, Dengan Maksud Agar Masyarakat Terlindungi Ketika Memperoleh Pelayanan Sampai Pada Proses Penyembuhan

Tanggung Jawab Pemerintah Tersebut Di Dukung Oleh Beberapa Aturan PerundangUndangan Serta Peraturan Yang Di Keluarkan Pemerintah, Salah Satu Aturan Tersebut Seperti Undang-Undang Nomor 36 Tahun 2009 Tentang Kesehatan, Pada Pasal 5 Ayat(1) Mengatur:

"Setiap Orang Mempunyai Hak Yang Sama Dalam Memperoleh Akses Atas Sumber Daya Di Bidang Kesehatan".

\footnotetext{
${ }^{1}$ Siregar Elizabeth dan Budhiartie Arrie, 2010, Majalah Hukum Forum Akademika, Jakarta, Hlm 172
} 
Anggapan Yang Timbul Dimasyarakat Moderen Bahwa Rumah Sakit Sebagai Salah Satu Tempat Pelayanan Kesehatan Yang Menyediakan Layanan Pengobatan Dan Perawatan Maupun Informasi Kesehatan Yang Di Tunjang Oleh Peralatan Yang Moderen Dangedung Serta Tenaga Ahli Yang Mempunyai Pengetahuan Dan Keterampilan Yang Baik Dalam Memberikan Pelayanan Kesehatan Guna Memberikan Pertolongan Kepada Pasien

Upaya Pelayanan Kesehatan Dengan Mengunakan Peralatan Medis Dengan Teknik Diagnostik Yang Tinggi Memungkinkan Untuk Selalu Bersentuhan Dengan Risiko, Demikian Pula Pengobatan Pada Penyakit Dengan Variatif Penyakit Yang Bermacam-Macam. Dengan Demikian Pemberi Pelayanan Kesehatan Dapat Memahami Risiko Dari Apa Yang Dilakukan Dalam Pelayanan Kesehatan. Berkaca Pada Setiap Kejadian Yang Terjadi Di Seluruh Indonesia Seperti Yang Ditangani Oleh $\mathrm{Mkdki}^{2}$ (Majelis Kehormatan Disiplin Kedokteran Indonesia) Yang Merupakan Kasus Dalam Pelayanan Kesehatan Bahwa Sejak Tahun 2006 Sampai Tahun 2012 Tercatat Ada 182 Kasus Kelalaian Medik, Sebanyak 60 Kasus Dilakukan Dokter Umum, 49 Kasus Oleh Dokter Bedah, 33 Kasus Oleh Dokter Kandungan Dan 6 Kasus Oleh Dokter Spesialis Anak Dan Sisa Dibawa 10 Ada Macam-Macam Kasus Yang Dilaporkan Yang Terbukti Dilakukan Oleh Tenaga Kesehatan Di Seluruh Indonesia.Serta Beberapa Kasus Yang Diungkapkan Oleh Tarigan Dalam Penelitiannya Mengemukakan Bahwa Pada Tahun 2013 Terdapat 7000 Nakes Terinfeksi Hepatitis B, Sekitar 4.900 Diantaranya Disebabkan Karena Kecelakaan Tertusuk Jarum Suntik, Sisanya Tertular Dari Penderita, Risiko Penularan Hepatitis B Kepada Petugas Kesehatan Mencapai 20 Sampai 40 Persen, Paling Tidak Mereka Tertusuk Jarum Suntik Sekali Dalam Setahun

Cerminan Pada Keadaan Seperti Ini, Dapat Memberikan Gambaran Kepada Setiap Rumah Sakit Dan Pusat Pelayanan Kesehatan Untuk Selalu Menerapkan Unsur Kehati-Hatian Dalam Melakukan Kegiatan. Kesalahan-Kesalahan Tersebut Turut Mempengaruhi Sistem Pelayanan Kesehatan Kedepan Yang Berhubungan Dengan Kepercayaan Masyarakat Terhadap Pelayanan Di Rumah Sakit. Untuk Itu, Guna Membantu Tenaga Kesehatan Dalam Upaya Mencegah Timbulnya Risiko Yang Terjadi, Pemerintah Mengupayakan Bentuk Perlindungan Guna Melindung Setiap Petugas Kesehatan Dalam Melakukan Tindakannya Dalam Bentuk Peraturan, Aturan Tersebut Misalnya Undang-Undang Nomor 36 Tahun 2009 Tentang Kesehatan Yang Pada Pasal 27 Mengatur:

"Tenaga Kesehatan Berhak Mendapatkan Imbalan Dan Pelindungan Hukum Dalam Melaksanakan Tugas Sesuai Dengan Profesinya".

${ }^{3}$ Kemampuan Menjalankan Tugas Dan Fungsinya Serta Bertanggung Jawab Akan Pelayan Merupakan Unsur Yang Berhubungan Dengan Risiko, Sehingga Pemerintah Membuat Atauran Yang Mengatur Tentang Risiko, Salah Satu Aturannya Adalah Undang-Undang Nomor 44 Tahun 2009 Tentang Rumah Sakit Yang Merupakan Pedoman Kewajiban Bagi Rumah Sakit Dalam Mengatur Pelayanan Yang Berefek Pada Risiko Yang, Semisalnya Undang-Undang No 44 Tahun 2009 Tentang Kesehatan, Pasal 43 Ayat (1) Mengatur :

"Rumah Sakit Wajib Menerapkan Standar Keselamatan Pasien".

Pedoman Standar Keselamatan Pasien (Patient Safety) Merupakan Pedoman Bagi Rumah Sakit Untuk Memberikan Pelayanan Pasien Yang Lebih Aman Dengantindakan Asesmen Risiko, Identifikasidan Manajemen Risiko Pasien, Pelaporan Dan Analisis Insiden, Kemampuan Untuk Belajar Dan Menindaklanjuti Insiden, Dan Menerapkan Solusi Untuk Mengurangi Serta Meminimalkan Timbulnya Risiko.Untuk Itu, Rumah Sakit Dapat

\footnotetext{
${ }^{2}$ Tabloid tempo. 2012, co Balikpapan, terjadi 182 kasus Malpraktek, Hlm 1

${ }^{3}$ Darmawi Herman, 2014,Manajemen Risiko, edisi empat belas. Bumi Perkasa.Jakarta,Hlm 5
} 
Mengunakan Suatu Bentuk Sistem Manajemen Yang Bisa Menanggulanggi Bentuk Risiko Yang Ditimbulkan Oleh Risiko Yang Tak Terduga Tersebut, Seperti Yang Dinyatakan Oleh ${ }^{4}$ Nolan Dalam "Eastern Mediterranean Health Journal" Bahwa "Sistem Manajemen Risiko Dirancang Untuk Membantu Mencegah Kesalahan"

Betapa Pentingnya Penerapan Suatu Manajemen Risiko Dalam Sistem Pelayanan Di Rumah Sakit, Pernyataan Tersebut Juga Dikemukakan Oleh ${ }^{5}$ Mamhuh $M$ Hanafi, Yang Mengatakankan Bahwa:

"Manajemen Risiko Adalah Suatu Pendekatan Terstruktur/Metodologi Dalam Mengelola Ketidakpastian Yang Berkaitan Dengan Ancaman. Untuk Menyikapi Risiko, Maka Strategi Yang Digunakan Untuk Mengelolanya

Adalah Dengan Pengelolaan Sumberdaya, Agar Dapat Menghindari Risiko Serta Mengurangi Efek Negatif Risiko Seperti Kematian, Dan Tuntutan Hukum".

${ }^{6}$ Risiko Merupakan Akibat Penyimpangan Dari Rencana Secara Tak Terduga, Dan Mengandung Ketidakpastian Sesuai Rencana, Sehingga Menimbulkan Kerugian Dan Tidak Terpisahkan Dari Setiap Kegiatan Manusia, Sehingga Mengisyrakatkan Kepada Rumah Sakit Untuk Melakukan Pekerjaannya Berdasarkan Pada Standar Kerja Guna Menghidar Dari Risiko Yang Terjasi. Pasal 53 Ayat (3) Undang-Undang No 36 Tahun 2009 Tentang Kesehatan Mengatur : "Pelaksanaan Pelayanan Kesehatan Sebagaimana Dimaksud Pada Ayat (1) Harus Mendahulukan Pertolongan Keselamatan Nyawa Pasien Dibanding Kepentingan Lainnya".

Sejalan Dengan Tuntutan Masyarakat Maka Pelayanan Kesehatan Dirumah Sakit Lebih Dapat Mengoptimalkan Kualitas Pelayanan Kesehatan Yang Merupakan Kewajiban Dari Petugas Kesehatan, Sebab Kebutuhan Akan Kesehatan Didasari Oleh Hak Memperoleh Pelayanan Kesehatan. Sehingga Betapa Pentingnya Melakukan Penelitian Tentang Penerapan Manajemen Risiko Dan Keselamatan Pasien Untuk Menjamin Perlindungan Hukum Bagi Pasien Dan Tenaga Kesehatan Pada Pelayanan Rumah Sakit Umum Daerah Abepura"

\section{PERUMUSAN MASALAH.}

\section{Teori perlindungan hukum.}

Perlindungan hukum merupakan 7 jaminan hukum yang sudah diikat dengan bentuk perjanjian dalam memberikan pelayanan kesehatan. Jaminan tersebut melindungi kepentingan-kepentingan Pasien baik menyangkut material maupun ideaal terhadap hal yang merugikannya karena tujuan hukum adalah untuk mengatur dan melindungi masyarakat secara damai . Kehidupan manusia tidak terlepas dari aturan, sebab manusia mempunyai kepentingan yang merupakan hak dan menjadi kewajiban bagi orang lain. Perlindungan hukum bagi tenaga kesehatan dan pasien adalah merupakan upaya yang sudah dijamin oleh pemerintah dalam bentuk aturan hukum, sehingga kepastian perlindungan tersebut memberikan jaminan rasa aman bagi petugas kesehatan selaku pelaksana kegiatan perawatan dan pasien sebagai subjek dari perawatan.

\footnotetext{
${ }^{4}$ Journal, Health Mediterranean Eastern Vol. 15, No. 5, 2009, Hlm 3

${ }^{5}$ M Hanafi Mamduh, Manajemen Risiko, edisi kedua, 2009, Yogyakarta UUP STIM YKPN, Hlm 78

${ }^{6}$ Wahjoepramono Julianta Eka,2012 Konsekwensi Hukum dalam Profesi Medik, Bandung,Karya Putra Darwati, Hlm 53.

${ }^{7}$ Chandra Mardi. Aspek Perlindungan Anak Indinesia, Analisis tentang Perkawianan Di bawah Umur, ed Pertama,Jakarta, kencana

2018, HIm 33.
} 
Terkadang sisi pandangan hukum terhadap kesalahan yang terjadi hanya di lihat dari sisi manusia dalam mewujudkan kepentingan hukum, dalam mengatasi keadaan yang demikian penyempunaan perangkat hukum sangat diperlukan karena perangkat hukum dapat menjadi alat "Social Control" untuk menjaga atau mempertahankan ketertiban dalam masyarakat dan dan dapat juga menjadi "social enginering" sebagai sarana untuk membawa masyarakat berkembang maju secara dinamis dibawah pengayoman hukum.

pendapat FH Van der Burg dkk yang mengatakan bahwa :

"Perlindungan hukum adalah upaya yang dilakukan oleh negara untuk melindungi masyarakat karena tindakan dan kelalaian melanggar hak-hak orang atau kelompok tertentu",

Dasar teori tentang perlindungan hukum diatas memberikan gambaran bahwa tentang pelayanan kesehatan yang di laksanakan berdasarkan upaya menghargai hak-hak akan pelayanan kesehatan, seperti makna yang terkandung dalam penjelasan Undang-Undang Nomor 36 Tahun 2009 dalam Bab II Asas Dan Tujuan pada Pasal 2 menegaskan tentang:"Pembangunan kesehatan diselenggarakan dengan berasaskan Perikemanusiaan, keseimbangan, manfaat, pelindungan, penghormatan terhadap hak dan kewajiban, keadilan, gender dan nondiskriminatif dan norma-norma agama",

\section{Perlindungan Hukum.}

Perlindungan hukum menurut phillipus $M$. Hadjon bahwa perlindungan hukum bagi rakyat sebagai tindakan pemerintah yang bersifat prefentif dan representif. Segala upaya perlindungan yang dilakukan oleh negara bersifat memberikan rasa aman kepada semua warga negara dengan maksud agar setiap merasa terlindungi dalam melakukan aktifitas kehidupannya yang sudah dilindungi oleh hukum

Mengacu pada pernyaaan pakar hukum diatas bahwa setiap manusia tanpa kecuali mempunyai hak yang dilindungi oleh hukum. Oleh karena itu dalam menjalani kehidupan manusia berusaha mempertahankan hidup sebagai makluk sosial guna memperoleh rasa aman. Pemahaman ini telah dijabarkan dalam Undang-Undang Dasar Negara Republik Indonesia Tahun 1945 pada Pembukaan alinea ke 4 mengatur :

"Kemudian dari pada itu untuk membentuk suatu Pemerintah Negara Indonesia yang melindungi segenap bangsa Indonesia dan seluruh tumpah darah Indonesia dan untuk memajukan kesejahteraan umum".

Konsep pelindungan hukum pada Negara Kesatuan Republik Indonesia merupakan bentuk dari penjabaran masing-masing dasar hukum yang melindunginya. Seperti dalam Undang-Undang Negara Republik Indonesia No 36 Tahun 2009 tentang Kesehatan, yang mana makna perlindungan hukum telah tersirat pada pasal 2 mengatur tentang:

"Pembangunan kesehatan diselenggarakan dengan berasaskan perikemanusiaan,keseimbangan, manfaat, perlindungan, penghormatan hak dan kewajiban, keadilan, gender dan nondiskriminatif dan norma-norma agama".

Sisi lain dari bentuk pelindungan terdapat dalam undang-Undang Negara No 44 Tahun 2009 Pasal 2 mengatur tentang:

"Rumah Sakit diselenggarakan berasaskan Pancasila dan didasarkan kepada nilai kemanusiaan, etika dan profesionalitas, manfaat, keadilan, persamaan hak dan anti diskriminasi, pemerataan, perlindungan dan keselamatan pasien, serta mempunyai fungsi sosial”. 


\section{Hak}

Hak adalah seperangkat kewenangan yang diperoleh seseorang baik berupa hak yang melekat sejak ia lahir sampai meninggalnya yang biasa disebut ${ }^{8}$ hak asasi manusia maupun yang muncul ketika melakukan interaksi sosial dengan sesamanya, Ciri yang melekat pada hak, menurut pakar hukum Fitzgeraald seperti yang ditulis kembali oleh Satjipto Raharjo mengatakan Hak itu dilekatkan kepada seseorang yang disebut sebagai pemilik atau subjek dari hak itu. la juga disebut sebagai orang yang memiliki titel dari barang yang menjadi sasaran dari hak.

Jika saya dikatakan memiliki hak atas suatu perbuatan sendiri, maka orang lain memiliki kewajiban membiarkan saya melakukannya. Jika mereka menghalangi saya, maka mereka melanggar kewajiban yang telah dibebankan oleh aturan hukum dan dikenai sanksi. Bahwa saya memiliki suatu benda, dari sudut pandang hukum artinya semua orang diwajibkan untuk tidak mengintervensi atas perbuatan saya terhadap benda tersebut. Jika mereka mengganggu atau merusaknya maka dikategorikan sebagai delik

Jadi tidak ada hak hukum karena itu terdapat pembedaan antara norma hukum yang memberi perintah atau melarang, dengan norma hukum yang mengijinkan.

\section{Kewajiban}

Kewajiban menurut Kamus Besar Bahasa Indonesia memberi pengertian bahwa merupakan sesuatu tindakan keharusan yang harus dilakukan, apabila dikaitkan dengan perlakuan yang dilakukan oleh manusia maka mempunyai makna bahwa segala sesuatu yang berhubungan dengan norma moral yang baik dan benar yang dipadang dari sisi hukum sebegai dasar perlakuan dalam masyarakat. ${ }^{9}$ Pengertian diatas juga di sampaikan oleh salah satu tokoh sosiologi hukum (Sociology Of Law) Eugen Ehrlich yang mengemukakan bahwa:

"Dalam kenyataan orang mematuhi aturan hukum dan memenuhi kewajiban hukumnya dalam banyak kasus tidak karena takut kepada sanksi yang ada dalam aturan hukum, tetapi karena alasan lain" .

Adapun kewajiban-kewajiban lainnya yang merupakan bentuk dari pemahaman terhadap hak seseorang dalam menjalankan aktifitas sosial, sehungga kewajibankewajiban tersebut dapat dikelompokkan menurut Curzon, seperti yang dikutip oleh Satjipto Raharjo yang mengatakan bahwa:

1. Kewajiban-kewajiban yang mutlak dan nisbi.

bahwa kewajiban yang mutlak adalah yang tidak mempunyai pasangan hak, seperti kewajiban yang tertuju kepada diri sendiri; yang dimana oleh masyarakat pada umumnya: yang hanya ditujukan kepada kekuasaan (Sovereign) yang membawahinya. Kekuasaan nisbi adalah melibatkan hak dilain pihak.

2. Kewajiban-kewajiban dan perdata.

Kewajiban publik adalah yang berkolerasi dengan hak-hak publik, seperti kewajiban dlam memenuhi hukum pidana. Kewajiban perdata adalah korelatif dari hak-hak perdata seperti kewajiban yang timbul dari perjanjian.

${ }^{8}$ Ali Zainuddin H, filsafat hukum, Sinar Grafika,Jakarta,2006,Hal 27

${ }^{9}$ Raharjo Satjipto,Ilmu Hukum cetakan ke 6,2006,Pt Citra Aditya Bakti, Bandung,Hlm 55 
3. Kewajiban-kewajiban yang positif dan negatif.

Kewajiban positif menghendaki dilakukannya perbuatan positif, seperti kewajiban penjual untuk menyerahkan barang kepada pembelinya. Kewajiban negatif adalah yang menghendaki agar suatu pihak tidak melakukan sesuatu, seperti kewajiban seorang untuk tidak melakukan sesuatu yang mengganggu milik tetangga.

4. Kewajiban-kewajiban universal,umum dan khusus.

Kewajiban universal ditujukan kepada semua warga negaraseperti yang timbul dari undang-undang. Kewajiban umum ditujukan kepada segolongan orang-orang tertentu,seperti orangasing dan orang tua(ibu dan bapak). Kewajiban khusus adalah yang timbul dari bidang hukum tertentu, seperti kewajiban dalam hukum perjanjian.

5. Kewajiban-kewajiban primer dan bersifat memberi saksi.

Kewajiban primer adalah yang tidak timbul dari perbuatan yang melawan hukum, seperti kewajiban seseorang untuk tidak mencemarkan nama baik orang lain yang dalam hal ini tidak timbul dari pelanggaran terhadap kewajiban yang lain sebelumnya.

6. Kewajiban yang bersifat memberi sangsi adalah yang semata-mata timbul dari perbuatan yang melawan hukum, seperti kewajiban tergugat untuk membayar gugatan pihak lain yang berhasil memenangkan perkara.

\section{Kewenangan Pemerintah Daerah dalam Bidang Kesehatan.}

Kewenangan berasal dari kata weweng yang berarti mempunyai atau mendapatkan hak dan kewajiban dalam melakukan suatu perbuatan, baik itu perbuatan sosial maupun perbuatan pribadi, untuk itu makna kalimat kewenangan mempunyai karakteristik menjalankan fungsi mengatur seseorang ataupun kelompok agar sesuai dengan aturan yang berlaku

Hidup sehat merupakan hak dan harapan setiap warga negara,harus didukung oleh bentuk pelayanan yang menunjang keadaan sehat tersebut, dan pemerintah mempunyai kewenangan dalam pemenuhan hak tersebut. Kewenangan yang merupakan kewajiban hukum tersebut tertuang dan sudah diatur dalam Undang-Undang Dasar Tahun 1945 pasal $28 \mathrm{H}$ ayat (1) mengatur tentang:

"Setiap orang berhak hidup sejahtera lahir dan batin, bertempat tinggal, dan mendapatkan lingkungan hidup yang baik dan sehat serta berhak memperoleh pelayanan kesehatan".

Tugas pemerintah daerah dalam pelayanan kesehatan kepada masyarakat merupakan bentuk pelimpahan kewenagan penugasan dari Pemerintah Pusat kepada daerah untuk melaksanakan sebagian urusan wajib Pemerintahan dan menjadi kewenangan Pemerintah Daerah, penugasan ini sudah diatur dalam Undang-Undang Pemerintah Daerah Nomor 23 tahun 2014 pasal 12 ayat (1) huruf (b) mengatur :

“Urusan Pemerintahan Wajib yang berkaitan dengan Pelayanan Dasar meliputi kesehatan"

sehingga pelayanan kesehatan merupakan hal wajib yang harus di laksanakan di daerah. Berkaitan dengan makna aturan diatas maka ada beberapa teori yang berhubungan dengan kewenangan pemerintah daerah seperti yang diungkapkan oleh Soekidjo Notoadmodjo yang menyatakan bahwa:

"Penyelenggaraan pelayanan kesehatan dilaksanakan secara bertanggung jawab,aman, bermutu serta merata dan Nondiskriminatif. 


\section{Pelayanan Kesehatan di Rumah Sakit.}

Pengertian pelayanan kesehatan menurut ${ }^{10}$ Levey dan Loomba, ditulis kembali oleh Azrul Aswar mengatakan bahwa bahwa:

"Setiap upaya yang diselenggarakan secara bersama-sama dalam suatu organisasi untuk memelihara dan meningkatkan kesehatan, mencegah dan menyembuhkan penyakit serta memulihkan keehatan perorangan, keluarga, kelompok ataupun masyaraka"

Perubahan sifat pelayanan kesehatan, dengan meningkatnya ilmu dan teknologi maka ketergantungan yang muncul terhadap berbagai peralatan kedokteran yang canggih, yang dapat menimbulkan dampak negatif yaitu makin renggangnya hubungan antara dokter dengan pasien yang dibentuk dari berbagai peralatan canggih yang di pergunakan, selain itu, mengakibatkan biaya kesehatan semakin mahal sehingga akan menyulitkan masyarakat dalam menjangkau pelayanan kesehatan

Peraturan Presiden No 72 Tahun 2012 tentang Sistem Kesehatan Nasional pasal 2 ayat (1) mengatur:

"Pengelolaan kesehatan diselenggarakan melalui pengelolaan administrasi kesehatan, informasi kesehatan, sumber daya kesehatan, upaya kesehatan, pembiayaan kesehatan, peran serta dan pemberdayaan masyarakat, ilmupengetahuan dan teknologi bidang kesehatan, serta pengaturan hukum kesehatan secara terpadu dan saling mendukung guna menjamin tercapainya derajat kesehatan yang setinggi-tingginya".

Dalam rangka menjangkau pelayanan kesehatan maka Rumah Sakit dapat lebih memperhatikan keberpihakan terhadap hak dan kewajiban masyarakat dalam memperoleh pelayanan kesehatan, serta kesanggupan rumah sakit dalam menndaklanjuti pelaksanaan keputusan dalam pelengelolahan pelayanan kepada masyarakat secara umum.

\section{Manajemen Risiko di Rumah Sakit.}

Manajemen yaitu seperangkat sumber daya berupa alat yang digerakkan oleh manusia dalam upaya mencapai tujuan tertentu. Sedangkan risiko (kamus besar bahasa indonesia) artinya suatu perbuatan yang mengakibatkan keadaan kurang menyenagkan atau merugikan. pernyataan ini dihubungkan dengan pengertian para ahli, maka seperti Williams A Numan yang mengatakan bahwa Risk Manajement is a rational attempt to reduce or avoid the consequences of loss or injury, terjemaan oleh Kasidi bahwa Manajemen risiko adalah suatu usaha secara rasional untuk menghindar atau mengurangi kerugian atau cedera.

Rumah Sakit adalah institusi pelayanan kesehatan bagi masyarakat yang sarat akan risiko dengan bentuk karateristik yang dipengaruhi oleh perkembangan ilmu pengetahuan kesehatan, kemajuan teknologi, serta kehidupan sosial ekonomi masyarakat.Pada umumnya konflik yang terjadi di Rumah Sakit diakibatkan oleh bentuk ketidakpuasaan pasien terhadap layanan kesehatan. Ketidakpusaan dikarenakan banyak kesalahan dalam pelayanan kesehatan, sehingga mengakibatkan kerugian, baik itu berupa cedera atau cacat permanen, bahkan kematian. memahami permasalahan yang terjadi, maka kesalahan sekecil apapun bisa di antisipasi dengan mengunakan penerapan manajemen risiko.

\footnotetext{
${ }^{10}$ Aswar Azrul, Pengantar Administrasi Kesehatan edisi ketiga,Binapura Angkasara Publishers 1980 Hlm 42
} 
Menurut Mamhud M Hanafi, mengatakan bahwa

"Manajemen Risiko adalah seperangkat kebijakan, prosedur yang lengkap, yang dipunyai organisasi, untuk mengelola, memonitor,dan mengendalikan eksposur organisasi terhadap risiko"

\section{Kewenanggan Rumah Sakit dalam Pengawasan Internal terhadap Manajemen Risiko Tenaga Kesehatan.}

Pengawasan Internal Rumah Sakit tersirat dalam Keputusan Menteri Kesehatan No 772 Tahun 2002 tentang Peraturan Internal, memberi pengetian bahwa peraturan adalah seperangkat aturan yang dibuat oleh pemegang kekuasaan dalam upaya meningkatkan kesadaran hukum serta kepekaan terhadap bentuk aturan yang wajib di jalankan.

Berkiblat pada arti peraturan maka Rumah Sakit sebagai tempat pelayanan kesehatan yang modern dengan bentuk sebuah organisasi yang sangat kompleks yang ditandai dengan padat modal, padat teknologi, padat karya, padat profesi, padat sistem dan padat mutu serta padat risiko sehingga tidak mengejutkan apabila kesalahan sangat mungkin terjadi dalam proses layanan tersebut, sehingga perlu dibuat suatu aturan dalam menunjang pelaksanaan pelaksanaan pelayan kesehatan di rumah sakit.

\section{METODA PENELITIAN.}

Penulisan tesis ini menggunakan ${ }^{11}$ metode pendekatan yuridis sosiologis yaitu pendekatan ilmu-ilmu sosial untuk memahami ilmu hukum sebagai gejalah-gejalah faktual dengan mengunakan langkah-langkah metode penelitian ilmu sosial. Penelitian ini dimaksudkan untuk dapat menjawab permasalahan mengenai bentuk penerapan manajemen risiko dan keselamatan pasien untuk menjamin perlindungan hukum bagi pasien dan tenaga kesehatan pada pelayanan rumah sakit. Pendekatan ini diharapkan dapat menggumpulkan dan penyajian data dengan mengunakan konsep-konsep dan teori-teori serta peraturanperaturan hukum yang berkaitan dengan pokok permasalahan penelitian. Dengan spesifikasi deskriptif analitis, yaitu mengambarkan permasalahan hukum tertentu yang terjadi pada objek penelitian kemudian di analisa dan dihubungkan dengan sumber hukum positif yang sedang berlaku agar memperoleh gambaran tentang kategori hukum yang terjadi. Yang kemudian memberikan gambaran secara keseluruhan tentang upaya penerapan manajemen risiko dan keselamatan pasien untuk menjamin perlindungan hukum bagi pasien dan tenaga kesehatan pada pelayanan Rumah sakit, dan mencari keterkaitan dengan permasalahan yang terjadi. Dengan lokasi penelitian pada Rumah Sakit Umum Daerah Abepura Kota Jayapura Propinsi Papua.

Metode penelitian ini berhubungan dengan Objek penelitian yang mana merupakan sumber data utama dari Rumah Sakit Umum Daerah Abepura guna memperoleh gambaran dan informasi yang berhubungan dengan tujuan penelitian. ${ }^{2}$ Data dikumpulkan dalam dua (2) tahapan yaitu dengan studi kepustakaan dan studi lapangan, Yang mana

Studi kepustakaan merupakan metode pengumpulan informasi dalam beberapa referensi seperti buku, majalah atau tabloit tentang Hukum, pengetahuan ilmiah yang mutahir ataupun pengetian baru tentang fakta dan ide yang bertujuan menjadi landasan teori

\footnotetext{
${ }^{11}$ S.Widanti A.dkk, 2009. Petunjuk Penulisan Usulan Penelitian dan Tesis. Magister Hukum Kesehatan Universitas katolik

Soegijapranata. Semarang. Hlm 7

${ }^{12}$ Suratman dan Dillah Phillips H., 2012,Metode Penelitian Hukum, Bandung,Alfabet Hlm 123
} 
mengenai permasalahan yang diteliti yang merupakan data sekunder guna melengkapi materi tesis. Sedangkan studi lapangan merupakan metode pengumpulan data dengan melakukan pengamatan langsung guna menghasilkan data yang akurat dan data tersebut belum di olah. Dari hasil pengamatan terlibat(kuantitatif) dengan pendekatan wawancara berdasarkan data pertanyaan yang di buat peneliti agar peneliti memperoleh jawaban dari Direktur maupun pejabat Rumah Sakit yang datanya berhubungan dengan permasalahan yang terjadi sesuai masalah penelitian.

Adapun jenis Datayang dibutuhkan adalah data primer dan data sekunder. Sedangkan yang disebut dengan Data primer yaitu data dasar yang belum diolah dan diperoleh dengan cara studi lapangan. Sedangkan data sekunder yaitu data diperoleh melalui studi pustaka berupa buku-buku, dokumen, peraturan perundang-undangan, peraturan daerah, peraturan pemerintah daerah, karya ilmiah, dan lainnya, dan yang berkaitan dengan permasalahan yang akan diteliti sehingga data sekunder disebut juga sebagai data penunjang dalam mempertajam analisa .

Jenis data menurut beberapa pakar penelitian seperti Soerjono Soekanto bahwa data dalam penelitian hukum dibagi menjadi tiga bahan hukum yaitu bahan hukum primer bahan hukum sekunder dan bahan hukum tertier

a. Bahan Hukum Primer ; bahan hukum yang mengikat dan terdiri atas norma-norma atau kaidah dasar misalnya Undang-Undang Dasar 1945, ketetapan MPR, Peraturan Peraturan, Undang-Undangan seperti :

1). Undang-Undang Dasar Tahun 1945 pasal $28 \mathrm{H}$ ayat (1).

2). Undang-undang Nomor 36 Tahun 2009 tentang Kesehatan.

3). Undang-Undang Nomor 44 Tahun 2009 tentang Rumah Sakit.

4). Undang-Undang Nomor 23 Tahun 2014 tentang Pemerintah Daerah.

5). Peraturan Menteri Kesehatan No 1691 Tahun 2013 tentang Keselamatan Pasien.

6). Keputusan Menteri Kesehatan Nomor 772 tahun 2002 tentang Pedoman Peraturan Internal Rumah Sakit (HBL).

7). Peraturan Presiden Nomor 72 Tahun 2012 tentang Sistem Kesehatan Nasional.

8). Peraturan Menteri Kesehatan Nomor 340 Tahun 2010 Tentang Klasifikasi Rumah Sakit.

9). Peraturan Daerah Propinsi Papua No 6 tahun 2014 tentang Jaminan Pembiayaan Pelayanan Kesehatan Masyarakat Papua.

10). Peraturan Daerah Propinsi Papua No. 7 Tahun 2010 tentang Pelayanan Kesehatan,

11). Peraturan Daerah Propinsi Papua Nomor 11 Tahun 2016 tentang Organisasi dan Tata Kerja Lembaga Teknis Daerah propinsi Papua.

12). Peraturan Gubernur Papua No 38 Tahun 2015 tentang Uraian Tugas dan Fungsi Rumah Sakit Umum Daerah Abepura.

b. Bahan Hukum Sekunder. Yaitu Bahan hukum yang yang erat hubungannya atau memberi penjelasan kepada bahan hukum primer dan dapat membantu menganalisa dan memahami bahan hukum primer misalnya Rancangan Peraturan perundang-undang, hasil karya ilmiah para sarjana, hasil-hasil penelitian.

c. Bahan Hukum Tertier ; Bahan yang memberikan petunjuk maupun penjelasan tentang bahan hukum primer dan sekunder misalnya ; Kamus Besar Bahasa Indonesia.

Dalam pengumpulan data dapat dipakai berbagai cara seperti; partisipasi, observasi, wawancara yang terdiri dari wawancara kedalam, wawancara informan kunci, diskusi kelompok terarah, tinjauan, dokumen. 
Untuk dapat melengkapi data tersebut diatas, juga dapat diperlukan (1). Penelitian berdasarkan biografi dan sejarah lisan dari subjek/objek penelitian. (2). Penelitian Foto yang berkaitan dengan objek penelitian. (3).penelitian yang mengambarkan keadaan suasana penelitian ketika pengumpulan data berlangsung.

Metode Analisis Data. Yang digunakan adalah setelah data terkumpul dari data dilapangan sesuai dengan tujuan penelitian kemudian di susun dan dianalisa secara kualitatif dengan mengunakan teori hukum, asas hukum , teori manajemen beserta peraturan perundangundangan yang terkait, sehingga dapat memperoleh gambaran tentang hasil penelitian setelah dilakukan proses tafsir, dan evaluasi data permasalahan penelitian.

\section{PEMBAHASAN}

\section{Gambar Umum Lokasi Rumah Sakit.}

Nama Kota Jayapura pada awalnya adalah Holandia, namatersebut di berikan oleh Kapten Sachse yang merupakan komandan tentara Belanda sekitar tahun 1910.

Gambar.1. Peta kota Jayapura

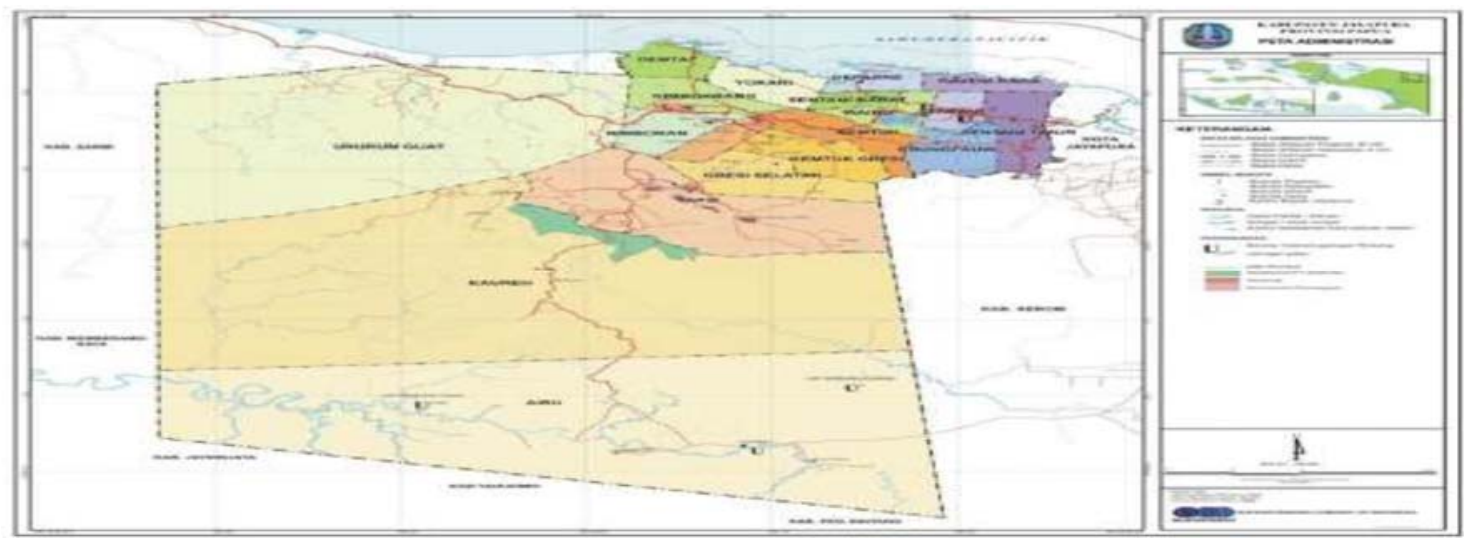

Sumber: Data BPS Propinsi Papua Tahun 2016

Tahun 1969 ditetapkan pembentukan Kabupaten Jayapura sebagai Daerah Otonomi dengan Ibu Kota Jayapura berdasarkan Undang-undang No.12 Tahun 1969 tentang Pembentukan Propinsi Otonom Irian Barat. Sepuluh (10) tahun setelah pembentukan daerah otonomi dengan ibu kota Jayapura, tepatnya tahun 1979 Kabupaten Jayapura dimekarkan dan memiliki Kota Administratif Jayapura yang dikukuhkan berdasarkan Peraturan Pemerintah RI No. 26 Tahun 1979 tertanggal 28 Agustus 1979 dengan wilayah yang meliputi dua Kecamatan yaitu Kecamatan Jayapura Utara dan Kecamatan Jayapura Selatan

\section{a. Letak Geografis Kota Jayapura'13.}

Kota Jayapura merupakan ibukota Propinsi Papua dan memiliki luas 940 Km2 (0.23\% dari luas daratan Provinsi Papua), dengan ketinggian $0-<700 \mathrm{~m}$ di atas permukaan laut (dpl), dengan batasan:Sebelah Utara: Lautan Pasifik, Sebelah Selatan: Kabupaten Keerom, Sebelah Timur: Negara Papua New GuineaSebelah Barat: Distrik Rafenirara Kabupaten Jayapura. WilayahKotaJayapura terdiri ataslima (5) Distrik yaitu Distrik Ja-

${ }^{13}$ Data Badan Statistik propinsi Papua Tahun 2016 
yapura Utara, Jayapura Selatan, Abepura, Heram dan Muara Tami. Sampai dengan tahun 2016, dan memiliki 14 Kampung dan 25 kelurahan yang terdiri dari 12 kampung asli yang didiami penduduk asli jayapura.

\section{b. Demografis Kota Jayapura.}

jumlah penduduk Kota Jayapura mencapai 288.786 jiwa, jumlah penduduk terbanyak berada di distrik Abepura yaitu 77.995 jiwa.

\section{c. Gambaram Umum Objek Penelitian.}

Rumah Sakit Umum Daerah Abepura adalah rumah sakit pemerintah yang terletak di Distrik Abepura kota Jayapura Propinsi Papua. Dahulu RSUD Abepura dikenal dengan sebutan Rumah Sakit Pembantu Abepura yang dibangun pada masa penjajahan Belanda status sebagai rumah sakit pembantu sesuai Surat Keputusan Gubernur KDH Propinsi Irian Jaya Nomor 445/1019/SET/1990, tanggal 23 Maret 1990 dan Surat Dirjen Yanmed No 601/Yanmed/RS/Budik/YMU/90, tertanggal 24 Agustus 1990 maka telah diterbitkan Surat Keputusan Gubernur KDH Tk I Irian jaya No 204 Tahun 1990 tentang penetapan Rumah Sakit pembantu Abepura menjadi Rumah Sakit Umum Abepura, dengan kapasitas tempat tidur 50 buah yang disesuaikan dengan dengan tingkat pelayanan kepada masyarakat. Berdasarkan Surat Keputusan Menteri Kesehatan No 1183/ MenKes/SK/XI/1994 Dan Keputusan Menteri dalam Negeri No 117 Tahun 1996 Rumah Sakit Umum Abepura ditetapkan menjadi rumah sakit kelas D Selanjutnya, berdasarkan Surat Keputusan Menteri Kesehatan nomor 491/Menkes/SK/V/1997 tanggal 20 Mei 1997, RSUD Abepura menjadi Rumah Sakit Tipe C.

\section{Kondisi Umum Objek Penelitian.}

Lokasi Rumah Sakit yang bersebelahan dengan pemukiman masyarakat yang memiliki luas areal $7.675 \mathrm{M}^{2}$ atau hanya sekitar $3 / 4$ ha dan belum mencapai 1 ha, terdapat bangunan gedung, areal taman dan parkir yang sangat terbatas. Sarana pelayanan RSUD Abepura meliputi sarana rawat jalan dengan 4(empat) buah poliklinik spesialis dasar (Bedah, Anak, Penyakit Dalam dan Kebidanan) serta poliklinik-poliklinik lainnya seperti Mata, THT, Saraf, Poliklinik Umum dan Gigi. Sarana penunjang medis yang dimiliki adalah sarana Radiologi/rontgen, Farmasi dan Laboratorium, Instalasi Gizi, Instalasi Sanitasi , Instalasi IPRS dan Instalasi Loundry. Sarana rawat inap yang dimiliki RSUD Abepura yaitu 163 tempat tidur yang tersebar di bangsal-bangsal pria, wanita, anak, bedah, kebidanan, bersalin, Perinatologi, ICU, UGD dan ruang kelas/VIP.

\section{Struktur Organisasi Pelayanan di Rumah Sakit}

Dalam struktur organisasi yang ada, sesuai Undang-Undang No 44 Tahun 2009 tentang Rumah Sakit pada pasal 33 Ayat (2) mengatur "Organisasi Rumah Sakit paling sedikit terdiri atas Kepala Rumah Sakit atau Direktur Rumah Sakit, unsur pelayanan medis, unsur keperawatan, unsur penunjang medis, komite medis, satuan pemeriksaan internal, serta administrasi umum dan keuangan.dengan peraturan, yang juga termasuk dalam aturan propinsi Papua yaitu Peraturan Gubernur Nomor 38 tahun 2015 tentang Uraian Tugas Fungsi dan Tugas Rumah Sakit Umum Daerah Abepura, dipimpin oleh seorang Direktur, bertugas memimpin dan menyelenggarakan kegiatan Rumah Sakit dan secara teknis Operasional bertanggungjawab kepada pemerintah daerah, tugas pokok Direktur Rumah Sakit dibantu oleh beberapa staf manajerial Rumah Sakit guna mengkoordinir sebagian beban tugas direktur.

\section{Sumber Daya Manusia di Rumah Sakit}

Keberadaan RSUD Abepura di kota Jayapura, merupakan pengamalan Pancasila yang mana pada sila ke 5 menjelaskan tentang keadilan, yang adil dalam pelayanan 
sekaligus merupakan bentuk kepedulian pemerintahSumber Daya Manusia dibidang Kesehatan pada RSUD Abepura Sejalan dengan Undang-Undang tentang Rumah Sakit pasal 12 Ayat (3) yang mengatur:

"Rumah Sakit harus memiliki data ketenagaan yang melakukan praktik atau pekerjaan dalam penyelenggaraan Rumah Sakit.

Rumah Sakit Abepura juga mempekerjakan beberapa tenaga ahli seperti beberapa diantaranya Spesialis Anak 3 orang, Spesialis Bedah 3 Orang, Spesialis Obgen/kebidanan 2 Orang, Spesialis Penyakit Dalam 3 Orang, Spesialis Patologi Klinik 1 Orang, Spesialis Radiologi 1 Orang, Spesialis Mata 1 Orang, Spesialis THT 1 Orang, Spesialis Kulit dan Kelamin 1 Orang, Spesialis Saraf 1 Orang, Spesialis Anastesi 1 Orang, Spesialis Forensik 1 Orang, Spesialis Orthopedi 1Orang dan Dokter Umum 21 Orang serta Dokter Gigi 7 Orang. Jumlah dokter yang memenuhi kuota Rumah Sakit type C ditambah dengan jumlah perawat dan bidan serta bagian administrasi memungkinkan sistim pelayanan menjadi lebih baik.

TABEL A.1. Jumlah Pegawai negeri sipil Rumah Sakit Umum Daerah Abepura berdasarkan Golongan Kepangkatan

\begin{tabular}{|c|c|c|c|c|}
\hline NO. & GOLONGAN & LAKI-LAKI & PEREMPUAN & JUMLAH \\
\hline 1 & I & 24 & 20 & 44 \\
2 & II & 177 & 227 & 412 \\
3 & III & 147 & 125 & 203 \\
4 & IV & 11 & 6 & 17 \\
\hline & Jumlah & 359 & 378 & 656 \\
\hline
\end{tabular}

Sejumlah 80 pegawai lain nya merupakan tenaga honorer dan kontrakan yang di perbantukan pada ruangan atau bansal rawat inap dan rawat jalan pada RSUD Abepura.

\section{Fasilitas Penunjang Pelayanan Kesehatan.}

Mengacu pada Keputusan Menteri Kesehatan No 56 tahun 2014 tentang Kalsifikasi dan Perijinan Rumah Sakit pada Pasal 36 mengatur tentang kelengkapan Pelayanan yang dimiliki oleh Rumah Sakit Umum kelas C paling sedikit meliputi: pelayanan medik; pelayanan kefarmasian; pelayanan keperawatan dan kebidanan; pelayanan penunjang klinik; pelayanan penunjang nonklinik; dan pelayanan rawat inap, dengan demikian Fungsi pelayanan di RSUD Abepura sudah melengkapi penunjang pelayanan seperti rawat jalan, rawat inap, rawat darurat. Instalasi penunjang tersebut adalah 1. Instalasi Rawat Intensif ; 2. Instlasi Bedah Sentral ; 3. Instalasi Rehabilitasi Medis; 4. Instalasi Radiologi; 5. Instalasi Farmasi; 6. Instalasi Gizi ; 7. Instalasi Laboratorium Klinik ; 8. Instalasi PemeliharaanSarana Rumah Sakit 9. Instalasi Sanitasi. prasarana penunjang lain seperti kebutuhan akan air bersih, diatur dalam Pasal 41 Keputusan Menteri Kesehatan No 56 tahun 2014 mengatur tentang pelayanan penunjang nonklinik meliputi pengelolaan air bersih, namun terdapat kendala air bersih dikarenakan harus di bagi dengan masyarakat yang berada di sekitar RSUD Abepura, mengingat lokasi rumah sakit di tengah pemukiman masyarakat. Hasil wawancara mengambarkan pengadaan air bersih, dengan membuat sumur bor dan bak penampungan air, dengan perimbangan pekerjaan dapat terealisasi pada awal tahun 2017. 


\section{Pengaturan Manajemen Risiko Dan Keselamatan Pasien.}

1. Tangungjawab Pemerintah Daerah Dalam Pengaturan Manajemen Risiko dan keselamatan pasien.

Dengan mengetahui macam Peraturan yang berlaku di Rumah Sakit semisal peraturan tentang keselamatan pasien yang dimaksudkan agar rumah sakit memahami isi dari peraturan dan membandingkan isi peraturan tersebut dalam kegiatan pelayanan di rumah sakit, dengan maksud apakah sudah sesuai dengan kebijakan atau masih terdapat banyak keseimpangan dalam penata kelolaan keselamatan pasien di rumah sakit agar tidak mengakibatkan permasalahan. berhubungan dengan keselamatan pasien pemerintah menerbitkan Keputusan Menteri Kesehatan No 1691 tahun 2011 tentang Keselamatan Pasien Rumah Sakit, pada Pasal 15 ayat (1) mengatur :

"Menteri, Pemerintah Daerah Provinsi dan Pemerintah Daerah Kabupaten/Kota secara berjenjang melakukan pembinaan dan pengawasan terhadap kegiatan Keselamatan Pasien Rumah Sakit sesuai tugas dan fungsi masing-masing".

Keterlibatan pemerintah daerah dalam pembinaan serta pengawasan keselamatan pasien di rumah sakit, merupakan kewajiban sebab Rumah Sakit Umum Daerah Abepura merupakan rumah sakit Pemerintah yang berada di kota Jayapura Distrik Abepura. Berkaitan dengan keselamatan pasien, maka rumah sakit lewat pemerintah daerah perlu menetapkan atau membuat suatu kebijakan tentang keselamatan pasien di rumah sakit. acuan tersebut berupa aturan intenal rumah sakit yang bersifat mengatur sistem pelayanan yang berhubungan dengan risiko pasien, dan diharapkan dapat mencegah terjadinya kesalahan akibat melaksanakan suatu tindakan Hasil penelitian yang dilakukan memberi gambaran bahwa peraturan internal RSUD Abepura yang sedang dibuat oleh pemerintah daerah sebagai pemilik sarana pelayanan masih dalam proses penyelesaian peraturan. Berkaitan dengan aturan internal maka RSUD Abepura harus mempunyai beberapa aturan semisal Hospital by Low dan standar operasional prosedur. yang bersifat mengontrol unsur keselamatan pasien, yang pengaturannyadisesuai dengan keadaan diRumah Sakit. Keputusan Menteri Kesehatan No 772 Tahun 2002 tentang Pedoman Pengaturan Internal Rumah Sakit mengatur :

"Pemilik Rumah Sakit atau yang mewakili mempunyai peran utama dalam pengaturan aturan internal rumah sakit, Tingkat dan jenis aturan internal rumah sakit disusun dan ditetapkan oleh pemilik rumah sakit atau yang mewakili selain itu dan berwenang menetapkan peraturan internal dirumah sakit".

Dalam Undang-Undang No 44 tahun 2009 tentang Rumah sakit pada Pasal 29 huruf (r) yang mengatur : "Setiap Rumah Sakit mempunyai kewajiban menyusun dan melaksanakan peraturan internal Rumah Sakit (hospital by laws)". penjelasan kedua aturan diatas menjelaskan bahwa bentuk kerja sama antara pemilik sarana pelayanan dan direktur dalam menyelesaikan format dan materi isi aturan internal, yang selanjutnya isi dari peraturan tersebut didukung oleh pendapat, saran dan masukanmasukan tentang pelaksaan kegiatannya dari RSUD Abepura, guna perbaikan materi peraturan interen tersebut.

\section{Peranan Rumah Sakit dalam pengaturan Manajeman Risiko dan Keselamatan Pasien.}

Rumah Sakit merupakan suatu lembaga yang mengupayakan pelayanan kesehatan, maka pelaksanaan kegiatannya pun tidak terlepas dari menghormati hak dalam memperoleh pelayanan kesehatan. RSUD Abepura juga memberi peluang bagi masyarakat di Papua memperoleh pelayan kesehatan.Dalammelaksanakan tata kelola pelayanan kesehatan, rumah sakit selalu membutuhkan tenga kesehatanprofesional. 
yang berfungsi sebagai pengawasan jaminan keselamatan bagi pasien. Pengaturan manajemen risiko dan keselamatan pasien di Rumah sakit berhubungan dengan aturan hukum yang berlaku seperti yang diatur dalam Undang-undang No 44 Tahun 2009 tentang rumah sakit. semisal Pasal 43 ayat (1) yang mengatur: "Rumah Sakit wajib menerapkan standar keselamatan pasien".

Rumah Sakit wajib menerapkan standar keselamatan pasien yang pelaksanaannya berfungsi mengguranggi bentuk risiko yang terjadi tanpa diduga. Kewajiban bagi Rumah Sakit Abepura tersebut memberikan kepastian perlindungan hukum bagi pasien dan tenaga kesehatan.Pelaksanaan jaminan perlindungan hukum bagi di rumah sakit Abepura , terkait dengan keberadaan aturan intenal yang ada. Namun dari hasil wawancara mengambarkan bahwa RSUD Abepura acuan yang dipakai sebagai dasar hukum dalm melakukan kegiatan di rumah sakit masih sebatas peraturan daerah yang ada, dan makna perlindungan termaktup dalam peraturan tersebut. Semisal Peraturan Daerah Propinsi Papua No. 7 Tahun 2010 tentang pelayanan kesehatan pada pasal (1) haruf (a) mengatur: "Tenaga Kesehatan berhak memperoleh perlindungan dalam melaksanakan tugas pelayanan kesehatan" kemudian dalam pasal 1 huruf (e) mengatur: "Tenaga kesehatan berhak memperoleh perlindungan hukum dari pemerintah daerah"

Penyelenggaraan pelayanan kesehatan tidak terlepas dari peran aturan dalam Rumah Sakit Untuk itu peran Rumah Sakit harus dilandasi oleh aturan agar memberikan arah pada sistem pelayanan. Mengacu pada pengaturan manajemen risiko dan keselamatan pasien maka Pemerintah Daerah Papua membuat aturan yang menjelaskan tentang uraian tugas pengaturan dan pengawasan terhadap pelayanan berda pada seksi pelayanan medis, seperti yang diatur dalam Peraturan Gubernur Papua No 38 Tahun 2015 tentang Uraian Tugas dan Fungsi Rumah Sakit Umum Daerah Abepura, yang pada Pasal 8 ayat (1) huruf (e) mengatur tentang: Seksi Pelayanan Medis mempunyai tugas melakukan pengelolaan pelayanan medis rumah sakit serta melakukan koordinasi penyelenggaraan keselamatan pasien. Fungsi Pengaturan manajemen risiko dan keselamatan pasien bagi seksi ini bersifat koordinasi pelayanan agar menghasilkan mutu keselamatan pasien.

\section{a. Penerapan Manajemen Risiko dan Keselamatan Pasien.}

Penerapan manajemen risiko berhubungan konsep risiko dalamupaya untuk menghindar atau menggurangi kerugian akibat melakuan suatu tidakan dalam pelayanan kesehatan di rumah sakit.Penerapan manajemen risiko dan keselamatan pasien merupakan proses untuk membantu rumah sakit dalam pengambilan keputusan menjalankan peran pemantauan dan penilaian terapan program keselamatan pasien rumah sakit sesuai dengan kesangupan rumah sakit dalam mengelola pelayanan kesehatan yang bermutu, prinsip aturan tersebut memiliki nilai tangung jawab terhadap unsur keselamatan bagi seluruh masyarakat dalam upaya memperoleh pelayanan kesehatan. Beberapa upaya dari rumah sakitguna memahami konsep risiko dengan jelas sepertidalam upaya memberikan unsur keselamatan bagi masyarakat dalam memperoleh pelayanan kesehatan yang selalu di dukung oleh aturan iteren dalam rumah sakit Aturan internal dapat berupa hospital by low dan standar operasional prosedur merupakan bentuk aturan hukum yang dibuat Pemerintah Daerah untuk menjaminan perlindungan hukum, sebab unsur keselamatan pasien merupakan bentuk upaya yang menjadi priorotas utama dalam melakukan pelayanan kepada masyarakat dengan indikasi tersentuh oleh masyarakat golongan ekonomi lemah di Papua. 


\section{Kewenangan Pelaksanaan Manajemen Risiko dan Keselamatan Pasien di Rumah Sakit}

Pelaksanaan manajemen risiko dan keselamatan pasien mempunyai sifat sebagai upaya melindungi pasien dan tenaga kesehatan sehingga kegiatan tersebut merupakan bagian yang tak terpisah dengan peran masing-masing unsur dalam organisasi.Peraturan internal Rumah sakit yang masih dalam proses pembuatan,Proses memahami prosedural tugas dan fungsi masing-masing bidang pelayanan di rumah sakit dapat mengacu pada aturan yang lebih tinggi, untuk itu setiap aturan mempunyai asas legalitas terhadap setiap pekerjaan yang mana pelaksanaan pekerjaan harus di pedomani dengan aturan hukum yang berlaku, semisal paham asas hukum

"lex superiori derogate lex inferiori " yang mana kandungan makna hukumnya mengisyaratkan bahwa makna hukum yang tinggi atau unggul mengabaikan atau mengesampingkan hukum yang lebih rendah, sehingga mengisyarakan kepada Rumah Sakit Abepura agar melakukan pelyanan sesuai aturan, maka tangung jawab dalam pengaturan pelayanan kesehatan mengacu pada aturan yang lebuh tinggi di daerah semisal Peraturan Daerah No 7 Tahun 2011 tentang pelayanan kesehatan. Tugas serta tangung jawab pelaksanaan manajemen risiko dan keselamatan pasien sudah diatur dalam Keputusan Presiden No 77 Tahun 2015 tentang Pedoman Organisasi Rumah Sakit. pada Pasal 19 ayat (1) mengatur :

"Selain Komite Medis sebagaimana dimaksud dalam Pasal 17, dapat dibentuk komite lain untuk peny=

elenggaraan fungsi tertentu di Rumah Sakit sesuai kebutuhan dan perkembangan ilmu pengetahuan dan

teknologi dalam rangka meningkatkan mutu pelayanan dan keselamatan pasien".

selanjutnya pada ayat (2) huruf (g) mengatur tentang

"Komite lain sebagaimana dimaksud pada ayat (1) dapat berupa komite manajemen risiko dan keselamatan pasien".

Dengan mengacu pada Peraturan Presiden tersebut maka Pemerintah Daerah mengeluarkan peraturan untuk menjalankan fungsinya sebagai koordinator dan pengawasan bidang manajemen risiko dan keselamatan pasien, seperti Peraturan Gubernur Papua No 38 Tahun 2015 tentang Uraian Tugas dan Fungsi Rumah Sakit Umum Daerah Abepura, yang mana pada Pasal 8 ayat (1) huruf (e) mengatur tentang:

"Seksi Pelayanan Medis mempunyai tugas melakukan pengelolaan pelayanan medis rumah sakit serta

melakukan koordinasi penyelenggaraan keselamatan pasien".

Tugas tangung jawab yang di berikan direktur kepada seksi tersebut agar menjalankan fungsinya dalam mengkoordinir pelaksanaan manajemen risiko dan keselamatan pasien yang dibebankan pada Seksi Pelayanan Medis merupakan pelimpahantugas Direktur RSUD Abepura, mengingat tugas tersebut sangat berat maka Direktur RSUD Abepura hanya bersifat mengontrol pelaksanaan manajemen risiko dan keselamatan pasien.

\section{Pelaksanan Manajemen Risiko dan Keselamatan Pasien oleh Tenaga Kesehatan.}

kapasitas ruangan pelayanan serta beban kerja di Rumah Sakit harus disesuaikan dengan kapasitas dan beban kerja agar kemungkinan yang bersifat merugikan pelayanan dapat diatisipasi. Keadaan tersebut sudah diatur dalam Pasal 23 Peraturan Menteri Kesehatan No 56 Tahun 2014 tentang Klasifikasi dan Perizinan Rumah Sakit mengatur 
"Jumlah dan kualifikasi tenaga kesehatan lain dan tenaga nonkesehatan disesuaikan dengan kebutuhan pelayanan Rumah Sakit”.

Dengan jumlah tenaga kesehatan di RSUD Abepura mencapai 700 staf yang terdiri dari PNS, ASN, dan tenaga kontraksekitar 160 perawat dan bidan, dan secara keseluruhan tenaga kesehatan yang adadapat mengurangi bentuk risiko pada pasien, maka Undang-Undang No 44 Tahun 2009 tentang Rumah Sakit pada Pasal 12 ayat (3) mengatur:

"Setiap tenaga kesehatan yang bekerja di Rumah Sakit harus bekerja sesuai dengan standar profesi, standar pelayanan Rumah Sakit, standar prosedur operasional yang berlaku, etika profesi, menghormati hak pasien dan mengutamakan keselamatan pasien".

Mengungkap standar pelayanan yang maksimal dapat diasumsikan bahwa pelayanan kesehatan harus dilaksanakan sesuai dengan aturan hukum dana secara bersama-sama agar tidak menimbulkan resiko, mengingat hasil yang diharapkan maksimal, ungkap tersebut sesuai dengan pendapat Levey dan Loomba yang ditulis kembali oleh Azrul Aswar yang mengatakan :

"Setiap upaya yang diselenggarakan secara bersama-sama dalam suatu organisasi untuk memelihara dan

Meningkatkan kesehatan, mencegah dan menyembuhkan penyakit serta memulihkan kesehatan perorangan,

keluarga, kelompok ataupun masyarakat"

Makna Undang-undang dapat memberi gambaran bahwa pelayanan maksimal maka dibutuhkan tenaga profesional sesuai standar profesi yang sesuai sehingga dapat mengurangi dampak risiko yang ditimbulkan dalam melakukan kegiatan pelayanan di rumah sakit.

\section{Kelengkapan fasilitas dalam menjamin Pelaksanaan Manajemen Risiko dan Keselamatan Pasien.}

Kelengkapan fasilitas penunjang dalam pelayanan kesehatan memiliki peran penting dalam meminimalisir bentuk risiko yang terjadi dalam pelayanan medis, sebab setiap kejadian atau penunjang kejadian yang berpontesi menghasilkan resiko harus dihindari atau diperbaiki agar tidak menimbulkan risiko tersebut menjadi lebih besar seperti halnya kelengkapan fasilitas.

Upaya mengatur sistem pelayanan di RSUD Abepura, semisal peran pemerintah daerah dalam merealisasi bantuan dana, Guna kelancaran tugas dan fungsi pelayanan kesehatan di Rumah sakit. Undang-Undang No 44 Tahun 2009 tentang Rumah sakit yang mengisyaratkan bahwa rumah sakit memiliki kewajiban dalam memberikan pelayanan yang aman yang ditunjang oleh fasilitas yang memadai, seperti yang diatur pada Pasal 29 ayat (1) huruf (b) bahwa

"Setiap Rumah Sakit mempunyai kewajiban memberi pelayanan kesehatan yang aman, bermutu,

antidiskriminasi, dan efektif dengan mengutamakan kepentingan pasien sesuai dengan standar pelayanan

Rumah Sakit"

melengkapi beberapa gedung yang sudah ada dan memenuhi standar rumah sakit, maka kelengkapan tersebut dapat menggurangi atau meminimalisir risiko yang ada. Dalam upaya 
pelaksanaan manajemen risiko dan keselamatan pasien dalam menunjang bentuk perlindungan pasien, maka seharusnya sistem pelayanan yang dilakukan selalu membutuhkan ketepatan waktu dan keakuratan dalam menindaklanjuti suatu diagnosa, sehingga dapat mengurangi bentuk risiko yang diakibatkan oleh keterlambatan dalam memaksimalkan waktu pelayanan.

\section{Kelengkapan Prasarana Dalam Menunjang Pelaksanaan Manajemen Risiko dan Keselamatan Pasien.}

Upaya perlindungan dalam menolong pasien juga menunjang pelaksanaan manajemen risiko dalam mengurangi sebab yang berpontesi menghasilkan resiko, sehingga prasarana penunjabng seperti geung dirasakan sangat penting guna memberikan rasa aman bagi penerima pelayanan serta mengurangi kapasitas menimbulkan risiko pelayanan. UndangUndang No 44 Tahun 2009 tentang Rumah sakit pasal 9 ayat (1) huruf (b) yang mengatur:

"Persyaratan teknis bangunan Rumah Sakit, sesuai dengan fungsi, kenyamanan dan kemudahan dalam

pemberian pelayanan serta perlindungan dan keselamatan bagi semua orang termasuk penyandang cacat,

anak-anak, dan orang usia lanjut".

Hasil wawancara mengambarkan harapan penambahan sarana gedung guna memenuhi kapasitas daytampungjumlah pasien dapat memaksimalkan sistem pelayanan kesehatan yang ada agar warga masyarakat Papua bisa merasakan pelayanan selalu mengedepankan mutu pelayanan,

\section{A. Hambatan Penerapan manajemen Risiko dan keselamatan pasien \\ 1. Hambatan dalam sisi pengaturan penerapan.}

Pengaturan manajeman risiko rumah sakit tidak terlepas dari pelayanan. hambatan yang sering dijumpai ketika melakukan aturan sesuai perundang-undangan tentang rumah sakit. Aturan internal rumah sakit yang belum rampung maka pengaturan harus dilakukan dengan memaknai aturan dari pemerintah daerah semisal Peraturan Daerah No 7 Tahun 2010 tentang pelayanan kesehatan, hambatan lain yang menyebabkan pelayanan terganggu adalah tidak bekerja sesuai standar prosedur kerja yang ada, maka dapat menimbulkan kegagalan dalam bekerja, ataupun tidak mencapai tujuan yang diinginkan.Perihal keselamatan pasien adalah merupakan unsur yang saling berkaitan dalam melakukan tata laksana pelayanan medis, sehingga masih membutuhkan proses untuk menerapkan manajemen risiko dan keselamatan pasien yang lebih baik.

\section{Hambatan Pelaksanaan ditinjau dari sisi tenaga kesehatan.}

Tenaga kesehatan berkewenangan melakukan upaya kesehatan yang didukung oleh pernyataan legalitas melakukan pekerjaan oleh Dinas Kesehatan setempat, yang disebut Surat ljin Praktek. Berkenaan dengan kelengkapan tenaga kesehatan di rumah sakit Abepura maka pastilah rumah sakit akan sarat akan aktivitas, tenaga profesional bidang kesehatan, teknologi dan beberapa unsur lain Permasalahan dapat terjadi dalam rumah sakit dimanapun berada, sehingga dapat menimbulkan risiko bagi pelayanan kesehatan. Hambatan yang dijumpai jumlah ketenagaan yang melebih kapasitas rumah sakit sehingga dalam bertugas tidak mengunakan Standar Prosedur Operasional (SPO) sehingga tidak hatihati dalam bertindak.

\section{Hambatan Pelaksanaan ditinjau dari sisi manajemen rumah sakit.}

Risiko yang terjadi dalam pelayanan kesehatan seperti rumah sakit merupakan akibat dari kurang hati-hati dalam melakukan pekerjaan, terkadang tidak sesuai dengan Standar operasinal prosedur yang ada yang selalu berhubungan tingkat pengetahuan, peralatan penunjang medis yang memadai, sehingga kemungkinan mengakibatkan bentuk mencederahi pasien ataupun petugas kesehatan. Solusi yang diperlukan dalam mengantisipasi menggurangi risko adalah dengan pengaturan manajemen risiko dan 
keselamatan pasien rumah sakit, yang sekira mungkin dapat diterapkan di rumah sakit sehingga risiko tersebut dapat dikurangi atau di hindari serta dialihkan.

Konstribusi langsung terhadap penerapan manajemen risiko yaitu memberikan jaminan terhadap kualitas pelayanan, jaminan perlindungan hukum dalam melakukan pekerjaan pelayanan kesehatan di rumah sakit belum ditunjang oleh aturan internal rumah sakit. Hambatan pelaksanaan manajemen risiko dan keselamatan pasien adalah pihak RSUD Abepura lambat dalam merancang aturan internal rumah sakit, yang merupakan pedoman serta petunjuk kepada tenaga kesehatan. Keselamatan pasien diperuntukan dalam upaya memperbaiki kualitas pelayanan kesehatan,kerena tuntutan pelayanan kesehatan harus bermutu. Mutu pelayanan baik jika pelayanan dapat mengkafer semua lapisan masyarakat dan masyarakat dapat menilai mutu pelayanan di Rumah sakit Abepura

Manajemen rumah sakit dinilai kurang tanggap dalam mengambil tindakan yang masimal agar pasien tidak merasa terabaikan dalam berproses mendapat pelayanan yang segera dan bermutu.

\section{Hambatan Pelaksanaan ditinjau dari fasilitas penunjang.}

Fasilitas penunjang seperti yang dimiliki oleh RSUD Abepura, belum mampu menapung jumlah pasien yang ada di Abepura. aset fasilitas yang dimiliki oleh RSUD Abepura dan sebagian besar digunakanyang dibangun sejak tahun 2007 dan sudah tidak maksimal untuk menampung jumlah pasien, disamping itu ruangan digunakan menampung beberapa jenis pasien dengan beda jenis kelamin, semisal perawatan penyakit dalam bagi pasien pria digabung dengan pasien wanita sehabis operasi. Efek ketidak layakan ini menyebabkan berimbas pada bentuk penyebaran penyakit kepada pasien yang lain dan juga sistem pengontrolan pengobatan pasien menjadi tidak efisien.Hambatan ini sebagai suatu parameter dalam menunjang keselamatan pasien, Upaya pihak rumah sakit membangun beberapa gedung tambahan yang sudah dapat dilengkapi dengan beberapa peralataan penunjang kegiatan medis dengan maksud beberapa fasilitas tambahan tersebut diperuntukan guna meningkatkan pelayanan kesehatan.

\section{PENUTUP}

\section{SIMPULAN}

simpulan tentang penerapan manajemen risiko dalam menjamin perlindungan hukum bagi

pasien dan tenaga kesehatan sebagai berikut :

1. Hasil penelitian mengambarkan bahwa jaminan perlindungan hukum bagi pasien dan tenaga kesehatan yang didukung oleh pengaturan manajemen risiko di rumah sakit, belum sepenuhnya didukung oleh perangkat hukum dalam interen rumah sakit dikarenakan peraturan internal seperti Hospital By Low sebagai pedoman pengaturan pelaksanaan pelayanan di rumah sakit masih dalam proses perancangan baik materi maupun isi sehingga secara keseluruhan sistem pelayanan masih bergantung pada peraturan daerah yang dibuat oleh Pemerintah Daerah. Pemberlakuan asas manfaat dari peraturan Daerah dapat dikatakan mampu mengkafer sebagian pelaksanaan pelayanan di rumah sakit secara keseluruhan. Penelitian membuktikan bahwa dengan adanya peraturan daerah tersebut maka upaya pelayanan, keselamatan pasien dan perlindungan hukum pada pasien dan tenaga kesehatan dapat di lakukan. Makna pasal dalam Peraturan Daerah Propinsi Papua no 7 tahun 2010 bersifat melindungi tenaga kesehatan dalam melakukan pekerjaannya di rumah sakit, sedangkan bagi masyarakat atau pasien miskin yang ada di Propinsi Papua sudah mendapat perlindungan dari pemerintah daerah dan dengan otomatis merupakan kewajiban yang harus di jalankan 
oleh Rumah Sakit Abepura adalah pelayana dengan Kartu Papua Sehat (KPS) yang mana pemberlakuan kartu papua sehat ini hanya di papua dan di peruntukkan bagi pasien miskin sampai pada bentuk rujukan ke rumah sakit diluar Papua.

2. Dari hasil penelitian mengambarkan bahwa Rumah Sakit Umum Daerah Abepura belum sepenuhnya melakukan penerapan manajemen risiko dan keselamatan pasien, dikarenakan dasar aturan internal rumah sakit yang dijadikan acuan dalam menyelesaikan setiap permasalahan dalam interen rumah sakit masih dalam proses pembuatan. Sehingga landasan yang dipakai dalam penerapan dalam melakukan pekerjaan secara keseluruhan masih berpedoman pada peraturan daerah yang ada guna menjamin perlindungan hukum bagi pasien dan tenaga kesehatan,maka dapat di simpulkan bahwa pihak Rumah Sakit Abepura berupaya melakukan jaminan keselamatan dengan berpedoman pada peraturan Daerah, yang merupakan bukti bahwa upaya pengawasan terhadap terselenggaranya proses manajemen risiko dan keselamatan pasien, dengan demikian dengan mengunakan peraturan daerah yang ada pihak rumah sakit dapat mengurangi dampak risiko yang ditimbulkan dalam melakukan ataupun tidak melakukan pelayanan.

3. Berdasarkan hasil penelitian yang dilakukan pada Rumah Sakit Umum Daerah Abepura tentang hambatan

dalam melakukan manajemen risiko dan keselamatan di rumah sakit untuk menjamin perlindungan hukum bagi pasien dan tenaga kesehatan dapat penulis simpulkan bahwa pihak rumah sakit belum sepenuhnya melakukan penerapan manajemn risiko dan keselamatan pasien karena fokus pelayanan masih pada perawatan primer saja, hal yang yang berkaitan dengan hambatan eraturan yang berlakuk di dalam rumah sakit, serta keterlibatan langsung semua staf dan petugas kesehatan belum dikatakan baik, yang didukung oleh kurang kesadaran akan bahaya yang akan ditimbulkan jika kurang hati-hati dalam pelayanan kesehatan di rumah sakit. Sisi lain yang berhubungan dengan hambatan melakukan penerapan manajemn risiko adalah tingkat kemahalan dalam memperoleh sarana penunjang pelayanan seperti alat medis penunjang diagnosa, obat, bahan habis pakai sehingga tidak dapat penuhi kebutuhan menyebabkan banyak risiko yang timbul karena tidak sistematis dalam melakukan pengawalan terhadap sistem manajemen risiko dan keselamatan.

\section{DAN SARAN,}

\section{Bagi Rumah Sakit Umum Daerah Abepura.}

a. Saran bagi Rumah Sakit Umum Daerah Abepura bahwa pengaturan manajemen risiko dan keselamatan pasien

dalam menjamin perlindungan hukum bagi pasien dan petugas kesehatan merupakan kewajiban yang dilakukan

di RSUD Abepura.Oleh sebab itu, maka rumah sakit harus membuat aturan internal dalam rumah sakit guna

memberikan perlindungan hukum bagi tenaga kesehatan yang melakukan pekerjaan pelayanan medis, dan juga

sebagai pedoman dalam memlkukan praktek pelayanan di Ruamh sakit, sebab resiko dalam pelayanan

kesehatan tak dapat di hindari tetapi dapat tetapi di kurangi selain itu pelayanan yang berpotesial

menimbulkan resiko dapat selalu dikawal agar tidak menyebabkan masalah bagi rumah sakit. 
b. Membimbing, membina, mengarakan tenaga kesehatansecara periodik dalam melakukan pelayanan dan selalu

berpedoman pada aturan internal yang ada di rumah sakit sehingga kerugian yang diakibatkan dari melakukan

pekerjaan bisa teratasi, disamping itu membuat selebaran tentang mutu baku prosedur pelayanan yang di

tempelkan pada setiap ruangan perawatan sehingga panduan ini bisa setiap hari di baca sehingga dengan

membaca dan dilakukan setiap hari maka akan tertanam apa yang menjadi dasar dalam melakukan perawatan

yang baik dan benar.

c. Dalam menunjang peningkatan mutu pelayanan rumah sakit perlu memotivasi tenaga kesehatan dengan secara

berkala melakukan sosialisai tentang manajemn risiko dan keselamatan pasien yang dilakukan setahun sekali

dalam kurun waktu enam bulan sekali.

d. Memotivasi kerja para petugas kesehatan dengan memberikan semacam hadiah bagi mereka yang dalam waktu

enam(6) bulan berturut-turut tidak pernah lalai ataupun alpa dalam melakukan pekerjaan sehingga dapat

memotivasi rekan kerja lainnya dalam melakukan pekerjaan yang mementingkan sisi kepentingan umum diatas

kepentingan pribadi atau golongan, sehingga keselamatan pasien menjadi prioritas dalam pelayanan di rumah

sakit abepura.

e.Rumah Sakit Umum Abepura Sesegera mungkin dapat membuat aturan Interen Rumah Sakit, Agar sistem

pelayanan bagi Rumah Sakit akan dilindungi Oleh aturan tersebut.

2. Bagi Pemerintah Daerah.

Pemerintah Daerah harus lebih aktif melakukan evaluasi dan monitoring serta pengawasan terhadap pelaksanaan keselamatan pasien di Rumah Sakit.

\section{Bagi Peneliti.}

Penelitian aturan perumahsakitan yang dilakukan di rumah sakit daerah seperti rumah sakit di Papua sedapat mungkin terus dilakukan oleh peneliti dari universitas yang ada di luar pulau papua agar memberi pengertian dan wawasan tentang peraturan wajib bagi rumah sakit yang disesuaikan dengan undang-undang perumahsakitan dilndonesia, sehingga kebijakan tersebut dapat di implementasikan merata di seluruh nusantara.

\section{Bagi Masyarakat.}

Dari gambaran penelitian yang dilakukan oleh peneliti dapat memberikan pentunjuk kepada masyarakat bahwa

evaluasi dan pengawasan juga harus di lakukan oleh masyarakat juga dapat secara langsung memberikan

perubahan bagi pengembangan sistem pelayanan di rumah sakit dalam upaya meningkatkan penerapan aturan

wajib yang harus dilakukan di rumah sakit abepura. 


\section{DAFTAR PUSTAKA}

Aswar Azrul, 1980 Pengantar Administrasi Kesehatan edisi ketiga,Binapura Angkasara Publishers

Anwar Azrul, 2010 Pengantar Administrasi Kesehatan edisi Ketiga,Binarupa Aksara publiser,Ciputat-Tanggerang,

Ali Zainuddin H, 2006 filsafat hukum, Jakarta Sinar Grafika,

Asshiddiqie Jimly dan Safa'at Ali M, 2006 Teori Hans Kelsen Tentang Hukum Sekretariat Jenderal \& Kepaniteraan Mahkamah Konstitusi RI Jakarta

Adisastro Wiku,2014,Sistem Kesehatan edisi kedua,PT. RajaGrafindo Persada. Jakarta.

Berita Satu.Com (2014), Jarum Suntik Tak Aman, 7000 Tenaga Kesehatan terinfeksi Hepatitis B, 16 Sep 2014.

Cahyono B. Suharjo J.B., 2013 Menjadi Pasien Cerdas, Kiat Memperoleh Layanan Medis Terbaik dan Aman, PT.Gramedia Pustaka Utama,Jakarta

Chandra Mardi. 2018 Aspek Perlindungan Anak Indinesia, Analisis Tentang Perkawinan Di bawah Umur ed Pertama, Kencana. Jakarta.

Darmawi Herman. (2014), Manajemen Resiko, edisi empat belas. Jakarta Bumi Perkasa.

Darmadi Hermawan, 2016 manajemen Risiko Edisi kedua,Sinar Grafika Offset,Jakarta

Eastern Mediterranean Health Journal, Vol. 15, No. 5, 2009.

Hanafi M Mamduh, Manajemen Risiko, edisi kedua, 2009, UUP STIM YKPN, Yogyakarta.

Herlambang Susatyo, (2016) Manajemen Pelayanan Kesehatan Rumah Sakit, Cara Mudah Memahami Manajemen Pelayanan Rumah Sakit dan Organisasi Pelayanan Kesehatan Lainnya, Gosyen Publising, Yogyakarta

Isfandyarie Anny,2005, Malpraktek dan Risiko Medik dalam Kajian Hukum Pidana (Prestasi Pustaka Publiser) cetakan Pertama.

Mertokusumo Sudikno, 2007 Mengenal Hukum Suatu Penghantar, Liberty , Jogyakarta

Korompis EC Grace,2015 Organisasi dan Manajemen Kesehatan, EGC,Jakarta

Kasidi, Manajemen Risiko edisi kedua, 2010, Ghalia Indonesia, Bogor

Soerjowinoto Petrus, 2013 Ilmu Hukum Suatu Penghantar (Buku panduan Mahasiswa, fakultas Hukum Unika Soegijapranata Semarang), Semarang.

Siregar Elizabeth dan Budhiartie Arrie (2010) Jakarta Majalah Hukum Forum Akademika.

Soewono Hendrojono H.,2007, Batas Pertanggungjawaban Hukum

Malpraktek Dokter dalam Transaksi Terupetik,Surabaya, Srikandi

Suratman dan Dillah Phillips H, 2012 Metode Penelitian Hukum, 2012, Alfabet Bandung.

Soemoele P.Tince, 2009, Alternatif Penyelesaian Sengketa Medik Di Rumah Sakit, Jakarta, PT.Mitra Grafindo.

Wahjoepramono Julianta Eka, 2012 Konsekwensi Hukum dalam Profesi Medik, karya putra darwati bandung.

Widanti S Agnes Dkk 2009. Petunjuk Penulisan Usulan Penelitian dan Tesis. Magister Hukum Kesehatan Universitas Katolik Soegijapranata. Semarang.

Raharjo Satjipto, 2012 Ilmu hukum,cetakan ketujuh, PT.Citra Aditya Bakti, Bandung

Raharjo Satjipto, 2006 Ilmu Hukum cetakan ke enam, PT Citra Aditya Bakti, Bandung

PT.Pupuk Kalimantan Timur edisi 2013, Pedoman Manjemen Resiko, Tahun 2013.

INTERNET

http://www.jamsosindonesia.com/cetak/printout/453.

Crockford, Neil (1986). An Introduction to Risk Management (2nd ed.). Woodhead-Faulkner. 0-85941-332-2.

Eastern Mediterranean Health Journal, Vol. 15, No. 5, 2009, hal 3.

Tabloid tempo.co,Balikpapan (2012), Sampai akhir tahun 2012, terjadi 182 kasus Malpraktek. 
UNDANG-UNDANG.

Undang-Undang Republik Indonesia Nomor 36 Tahun 2009 tentang Kesehatan.

Undang-Undang Republik Indonesia No 44 Tahun 2009 Tentang Rumah Sakit..

Peraturan Presiden Republik Indonesia No 72 Tahun 2012 Tentangsistem Kesehatan Nasional.

Keputusan Presiden Repiblik Indonesia no 77 Tahun 2015 tentang Pedoman Organisasi Rumah Sakit.

Keputusan Menteri Kesehatan No 56 tahun 2014 tentang Kalsifikasi dan Perijinan Rumah Sakit

Keputusan Menteri Kesehatan Republik Indonesia NO:2264 Tahun 2011 tentang Pelaksanaan Perijinan Rumah Sakit.

Keputusan Menteri Kesehatan Republik Indonesia No 1691 Tahun 2011 Tentang Keselamatan Pasien. 